\title{
Ekstraksi Nanoselulosa dengan Metode Hidrolisis Asam sebagai Penguat Komposit Absorpsi Suara
}

\author{
Henry Julianto, Moh. Farid dan Amaliya Rasyida
}

Departemen Teknik Material dan Metalurgi, Fakultas Teknologi Industri, Institut Teknologi Sepuluh Nopember (ITS) e-mail: mofaredo@gmail.com

\begin{abstract}
Abstrak-Kebisingan merupakan polusi suara yang berdampak negatif terlebih disektor transportasi. Saat ini serat alam banyak digunakan dikarenakan ekonomis, ramah lingkungan dan ringan. Terlebih pabrik pengolahan minyak kelapa sawit memberikan kontribusi limbah yang beragam yaitu dari limbah cair, gas, dan padat. Limbah kelapa sawit yang terdapat di Indonesia memiliki jumlah yang sangat banyak, menurut survey yang dilakukan saat ini, limbah Tandan Kosong Kelapa Sawit (TKKS) mencapai 20 juta ton. Karena limbah yang begitu banyak dan tidak terpakainya TKKS maka dibuatlah penelitian ini yang bertujuan untuk mengesktraksi nanoselulosa dari TKKS dengan metode hidrolisis asam yang akan digunakan sebagai filler dalam komposit sebagai penguat absorpsi suara. Pengujian yang dilakukan dalam penelitian ini meliputi Transmission Electron Microscope (TEM) dan Scanning Electron Microscope (SEM). Dari hasil pengujian dapat dilihat bahwa diameter serat terreduksi oleh $\mathrm{H}_{2} \mathrm{SO}_{4}$ hingga 5 - 9.1 nanometer dengan Transmission Electron Microscope (TEM) dan $290.4 \mathrm{~nm}$ dengan Scanning Electron Microscope (SEM). Nanoselulosa yang didapat cenderung menggumpal dikarenakan terjadinya ikatan vanderwalls antar partikel serat.
\end{abstract}

Kata Kunci-Absorpsi Suara, Hidrolisis Asam, Morfologi, Nanoselulosa, Serat Tandan Kosong Kelapa Sawit.

\section{PENDAHULUAN}

$\mathrm{K}$ EBISINGAN merpupakan polusi suara yang berdampak negatif terlebih disektor transportasi. Kendaraan bermotor berpartisipasi sebanyak 55\% dalam kebisingan yang terjadi. Menurut PerMenLH No.07 Tahun 2009 tentang ambang batas kebisingan kendaraan bermotor tipe baru menyatakan bahwa kendaraan bermotor memiliki ambang batas kebisingan ratarata $80 \mathrm{~dB}[1]$.

Pada perkembangannya, saat ini telah dikembangkan berbagai material komposit dari serat alam yang digunakan sebagai material peredam suara. Peredam suara atau absorber suara adalah salah satu bahan yang dapat menyerap energi suara dari sumber suara. Energi suara yang diserap oleh bahan akan dikonversikan menjadi bentuk energi lainnya, pada umumnya diubah ke energi kalor [2]. Beberapa absorption materials adalah fibers, glasswool, woven glass fiber dan sebagainya [3]. Komposit serat alami merupakan salah satu alternatif bahan absorber suara. Serat alam pada umumnya memiliki kemampuan menyerap suara khususnya dalam mengendalikan kebisingan.
Sifat Fisik-Mekanik dari Serat Kelapa Sawit [4]

\begin{tabular}{cc}
\hline \hline Property & Range \\
\hline Diameter $(\mu \mathrm{m})$ & $150-500$ \\
Microfibrillar angle $\left(^{\circ}\right)$ & 46 \\
Density $\left(\mathrm{g} / \mathrm{cm}^{3}\right)$ & $0.7-1.55$ \\
Tensile strength $(\mathrm{MPa})$ & $50-400$ \\
Young's Modulus $(\mathrm{GPa})$ & $0.57-9$ \\
Elongation at break $(\%)$ & $4-18$ \\
Tensile strain $(\%)$ & 13.71 \\
Light-weighted fiber length $(\mathrm{mm})$ & 0.99 \\
Cell wall thickness $(\mu \mathrm{m})$ & 3.38 \\
Fiber coarseness $(\mathrm{mg} / \mathrm{g})$ & 1.37 \\
Fines $(<0.2 \mathrm{~mm})(\%)$ & 27.6 \\
Rigidity index, $(\mathrm{T} / \mathrm{D})^{3} \mathrm{x} 10^{-4}$ & 55.43 \\
\hline \hline
\end{tabular}

Tabel 2.

Komposisi Kimia dari Serat Kelapa Sawit [4]

\begin{tabular}{lc}
\hline \hline \multicolumn{1}{c}{ Property } & Range \\
\hline Cellulose (\%) & $42.7-65$ \\
Lignin (\%) & $13.2-25.31$ \\
Hemicellulosa (\%) & $17.1-33.5$ \\
Holocellulose (\%) & $68.3-86.3$ \\
Ash content (\%) & $1.3-6.04$ \\
Extractives in hot water $(\%)$ & $2.8-14.79$ \\
Solubles in cold water $\left(30^{\circ} \mathrm{C}\right)(\%)$ & $8-11.46$ \\
Alkali soluble (\%) & $14.5-31.17$ \\
Alfa-cellulose $(\%)$ & $41.9-60.6$ \\
\hline \hline
\end{tabular}

Tandan Kosong Kelapa Sawit (TKKS) merupakan salah satu limbah yang terdapat di Indonesia. Serat TKKS digunakan pada penelitan ini dikarenakan jumlahnya yang cukup banyak dan kadar selulosa yang cukup tinggi dan lignin yang sedikit berkisar serta penggunaannya yang ekonomis, dapat diperbaharui, dan ramah lingkungan. Serat alam juga memiliki beberapa keunggulan yaitu densitas yang rendah, keuatan yang cukup tinggi, abrasivitas yang rendah, dan kemampuan biodegradable yang tinggi. Adapun sifat fisik dan mekanik serta komposisi dari Serat TKKS sendiri ditunjukan Tabel 1 dan Tabel 2. 


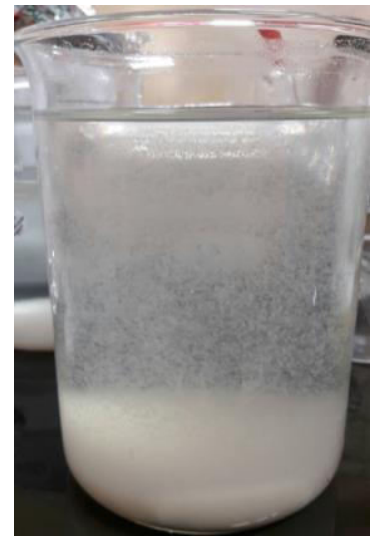

Gambar 1. Serat TKKS hasil hidrolisis asam.

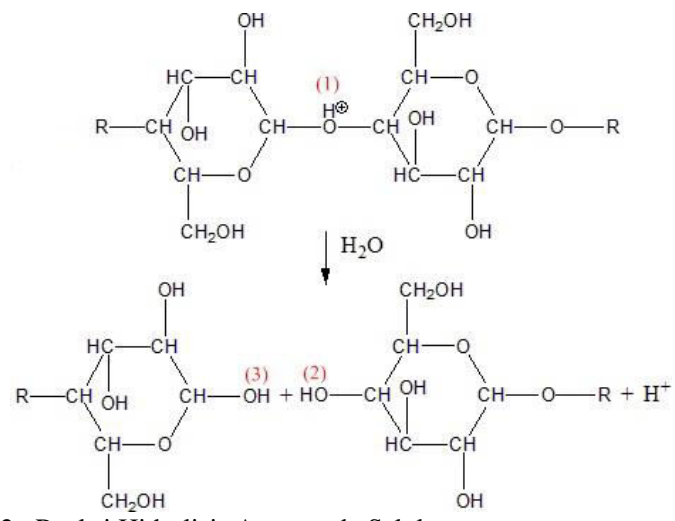

Gambar 2. Reaksi Hidrolisis Asam pada Selulosa.

Kadar selulosa dalam serat TKKS mencapai $42,7-65 \%$ dimana hal tersebut sangatlah baik untuk pembuatan nanoselulosa. Serat TKKS dengan densitas yang berbeda akan mempengaruhi absorpsi suara. Menurut Hee [5], Serat TKKS dengan densitas $292 \mathrm{~kg} / \mathrm{m}^{3}$ dapat menyerap suara rata-rata sebesar 0,9 pada frekuensi diatas $1 \mathrm{kHz}$. Begitu juga dengan ketebalan serat, semakin tebal serat maka koefisien absorpsi suara juga akan semakin meningkat.

Telah banyak penelitian mengenai pengaplikasian komposit dengan menggunakan serat alam sebagai material penyerap suara. Komposit polyester berpenguat bambu-rami dengan aspek rasio 90, nilai $\alpha$ serat rami mencapai 0.836 pada frekuensi $125 \mathrm{~Hz}$. Serat bambu mencapai nilai a 0.972 pada frekuensi $1000 \mathrm{~Hz}$. Terdapat kenaikan secara signifikan nilai koefisien absorbsi suara pada frekuensi $125 \mathrm{~Hz}$ untuk material poliester berpenguat serat rami dan pada frekwensi menengah $1000 \mathrm{~Hz}$ untuk material poliester berpenguat serat bamboo [6].

Penelitian Farid dan Tri (2013) mengatakan bahwa komposit poliester berpenguat serat rami pada frekuensi 1255 $\mathrm{Hz}$ memiliki nilai koefisien absorpsi suara $(\alpha)$ sebesar 0.835 [7].

\section{II.METODE PENELITIAN}

\section{A. Material}

Material yang digunakan dalam penelitian ini adalah serat Tandan Kosng Kelapa Sawit (TKKS) yang berasal dari PT. Intan Andalan. Kelapa sawit ditanam di Dumai, Riau dengan umur 6 tahun. Hasil TKKS dikenakan proses bleaching dengan

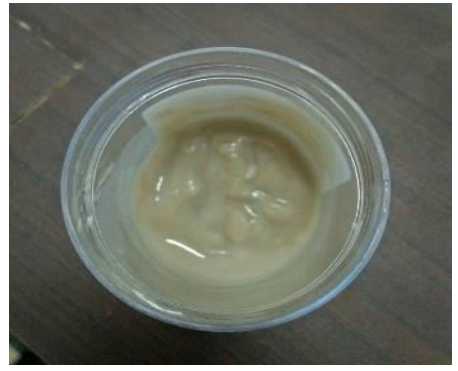

Gambar 3. Serat TKKS Hasil Hidrolisis dalam storage.

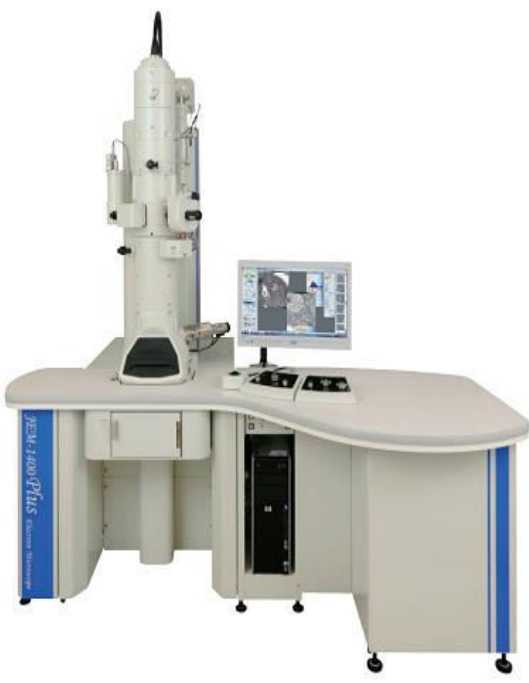

Gambar 4. TEM JEOL 1400 [10].

di-stirrer dengan $\mathrm{H}_{2} \mathrm{O}_{2} 7,2 \%$ wt dan $\mathrm{NaOH} 4 \%$ wt dengan diameter berkisar $40-60 \mu \mathrm{m}$ di atas hot magnetic stirrer dengan temperature $55^{\circ} \mathrm{C}$ selama $2 \mathrm{jam}$. Setelah dilakukan proses bleaching maka serat hasil proses bleaching di netralkan dengan larutan $\mathrm{H}_{2} \mathrm{SO}_{4}$ hingga $\mathrm{pH}=7$ (normal).

\section{B. Proses Hidrolisis Asam}

Pengolahan nanoselulosa diawali dengan adanya proses bleaching. Proses bleaching merupakan proses penghilangan lignin dan hemiselulosa dari serat TKKS yang diikuti dengan pengurangan diameter dari serat. Setelah itu serat yang sudah di-bleaching akan dikenakan $\mathrm{H}_{2} \mathrm{SO}_{4} 64 \%$ atau yang dinamakan dengan proses hidrolisis asam selama 45 menit dengan temperature $40^{\circ} \mathrm{C}$ dengan metode water bath. Perlakuan hidrolisis asam bertujuan untuk memecah bagian amorfus dari selulosa sehingga mereduksi ukuran serat sepeti yang ditunjukkan seperti Gambar 2. Ketika asam sulfat berdifusi ke dalam serat terjadi pemisahan ikatan glikosidik sehingga terjadi pemisahan fibril pada selulosa. Kondisi ini harus dijaga agar tidak terjadi hidrolisis sempurna glukosa [8]. Gambar 1 merupakan larutan hasil hidrolisis yang belum dinetralkan.

Setelah dilakukan hidrolisis asam lalu larutan dinetralkan hingga $\mathrm{pH}=7$ dengan larutan $\mathrm{NaOH}$. Setelah di netralkan, maka larutan akan di centrifuge dengan kecepatan putar 5000 rpm selama 15 menit di Laboratorium Limbah B3 Teknik Lingkungan ITS untuk mendapatkan endapan nanoselulosa.

Endapan Nanoselulosa dimasukkan ke dalam storage seperti Gambar 3. 


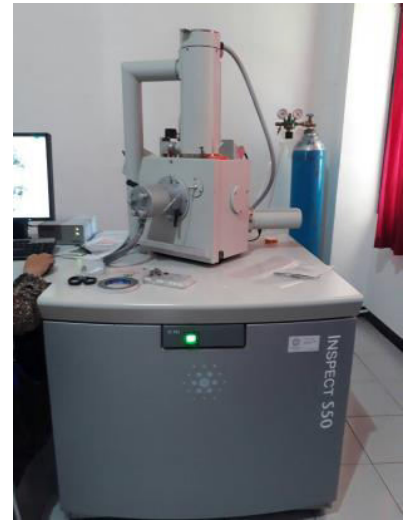

Gambar 5. SEM Inspect S50 [12].

Mengisolasi selulosa berukuran nano dari serat dapat dicapai dengan hidrolisis asam yang mengakibatkan suspensi koloid agregat [9]. Pada Gambar 2 menunjukkan reaksi hidrolisis asam pada selulosa. Asam sulfat yang diencerkan dengan air akan membentuk ion $\mathrm{H}_{3} \mathrm{O}^{+}$yang kemudian ion $\mathrm{H}^{+}$ bereaksi dengan salah satu cincin selulosa seperti pada Gambar 2 (1) membentuk ikatan O-H pada Gambar 2 (2). Reaksi ini menghasilkan $\mathrm{H}_{2} \mathrm{O}$ yang kemudian $\mathrm{H}_{2} \mathrm{O}$ akan bereaksi dengan cincin selulosa yang satunya membentuk ikatan O-H seperti pada Gambar 2 (3) dan menghasilkan ion $\mathrm{H}^{+}$. Nanoselulosa ditunjukkan pada Gambar 3.

\section{Pengujian Transmission Electron Microscope (TEM)}

Pengujian TEM memiliki fungsi untuk analisis morfologi, struktur kristal, dan komposisi spesimen. TEM menyediakan resolusi lebih tinggi dibandingkan SEM, dan dapat memudahkan analisis ukuran atom (dalam jangkauan nanometer) menggunakan energi berkas electron sekitar 60 sampai $350 \mathrm{keV}$. Mesin TEM yang digunakan adalah JEOL TEM 1400 seperti pada Gambar 4. TEM cocok untuk menjadi teknik pencitraan material padat pada resolusi atomik. Informasi struktural diperoleh dengan pencitraan resolusi tinggi dan difraksi elektron. Ketika elektron ditumbukkan pada sebuah permukaan material, dari permukaan tersebut akan dipancarkan elektron. Dari pancaran elektron ini bisa diketahui bentuk permukaan zat. Spesifikasi dari alat JEOL TEM 1400 adalah resolusi yang sangat tinggi hingga $0.2 \mathrm{~nm}$, tegangan sampai $120 \mathrm{kV}$, dan perbesaran dari 200 sampai dengan 1.200.000x.

Prinsip kerja dari TEM sendiri adalah Elekron ditembakan dan ditembuskan melewati objek spesimen dengan difokuskannya elektron oleh condenser lens. Lalu elekron akan mengenai fluorescent screen, dimana layar ini akan memancarkan cahaya jika dikenai elektron.

\section{D.Pengujian Scanning Electron Microscope (SEM)}

Pengujian ini memiliki fungsi untuk mengetahui morfologi, ukuran partikel, pori serta bentuk partikel material. Standar pengujian yang digunakan adalah ASTM E986 [11]. Mesin SEM yang digunakan adalah Inspect S50 seperti pada Gambar 5 dengan spesifikasi tegangan volt: $200 \mathrm{~V}-30 \mathrm{kV}$, arus: sampai dengan $2 \mu \mathrm{A}$, dan perbesaran: 13 to $1000000 \mathrm{x}$ untuk partikel, material berpori, dan serat serta komposit.

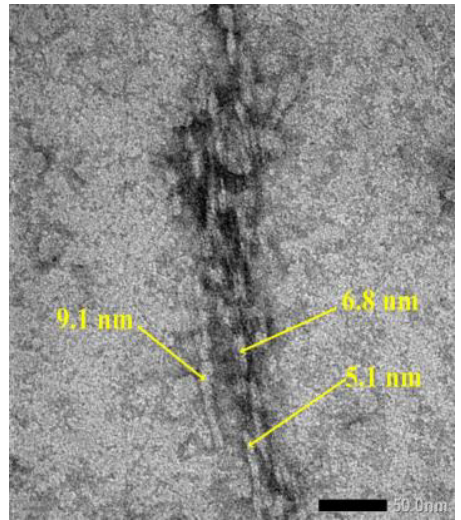

Gambar 6. TEM serat TKKS hasil hidrolisis asam dengan perbesaran 80000x.

Sampel yang digunakan berupa lembaran yang dilengketkan pada holder dengan menggunakan selotip karbon double tape. Kemudian dimasukkan ke dalam alat pelapis autofine-coater JFC-1100 untuk melapisi sampel dengan lapisan tipis Au-Pd (80:20). Lalu, sampel dimasukkan dalam specimen chamber pada alat SEM. Perbesaran yang digunakan adalah 50-1000 kali

Cara kerja SEM adalah dengan menembakkan elektron dari electron gun lalu melewati condencing lenses dan pancaran elektron akan diperkuat dengan sebuah kumparan, setelah itu elektron akan difokuskan ke sampel oleh lensa objektif yang ada dibagian bawah. Pantulan elektron yang mengenai permukaan sampel akan ditangkap oleh backscattered electron detector dan secondary electron detector yang kemudian diterjemahkan dalam bentuk gambar pada display.

\section{HASIL DAN PEMBAHASAN}

\section{A. Hasil Pengujian Transmission Electron Microscope}

Pengamatan morfologi dengan skala nanometer (nm) dari nanocellulose ditunjukkan pada Gambar 6. Gambar tersebut menunjukkan hasil pengujian TEM pada serat nanocellulose setelah proses hidrolisis asam.

Gambar 6. menunjukkan hasil serat TKKS setelah di hidrolisis, terlihat bahwa serat mengalami penggumpalan pada sebagian besar gambar dan terdapat sedikit serat tunggal. Struktur yang menggumpal/aglomerasi seperti ini menunjukkan fiber mengalami pemecahan. Hal tersebut dikarenakan proses hidrolisis yang memecah fiber-fiber selulosa. Masing-masing serat yang terdiri dari serat tunggal melekat bersama [13]. Hal ini terjadi karena adanya gaya tarik menarik Van der Waals antar nanopartikel tersebut [14]. Ukuran serat tunggal yang terlihat pada perbesaran 80000x sekitar $5.1-9.1 \mathrm{~nm}$.

\section{B. Hasil Pengujian Scanning Electron Microscope}

Pengamatan morfologi juga dilakukan dengan menggunakan Scanning Electron Microscope (SEM). Hasil pada serat setelah proses hidrolisis asam berkisar antara $291.4 \mathrm{~nm}$ sampai dengan $8242 \mu \mathrm{m}$ yang ditunjukkan pada Gambar 11. Jika dilihat dari morfologi serat mengalami aglomerasi satu dengan yang lain yang dikarenakan gaya tarik menarik Van der Waals [11]. 


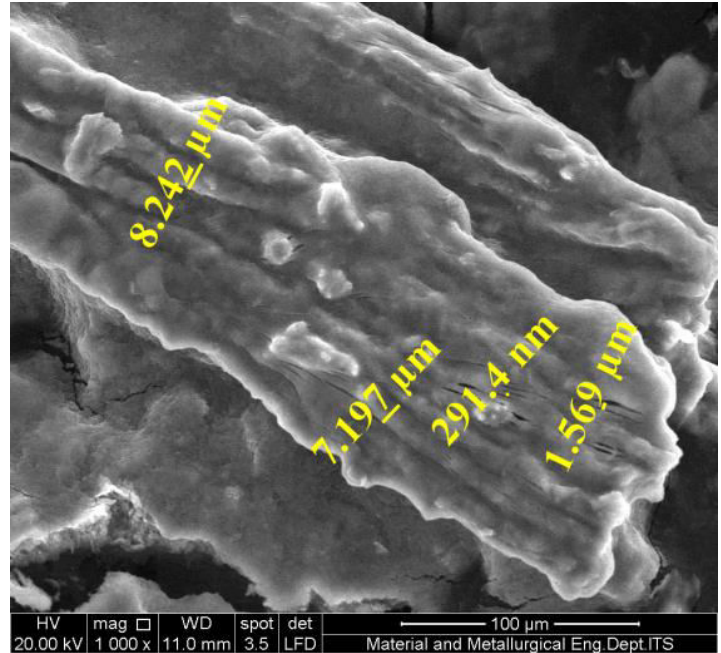

Gambar 7. SEM serat TKKS hasil hidrolisis asam dengan perbesaran 1000x.

\section{KESIMPULAN}

Proses hidrolisis asam dari serat tandan kosong kelapa sawit menghasilkan selulosa yang berukuran nano. Hasil SEM menunjukan diameter serat sebesar $291.4 \mathrm{~nm}$ sampai dengan $8242 \mu \mathrm{m}$. Reduksi serat dari proses bleaching hingga hasil hidrolisis sebesar 91.65\%. Pengujian TEM menunjukkan diameter serat tunggal yaitu $5.1-9.1 \mathrm{~nm}$.

\section{UCAPAN TERIMA KASIH}

Penulis berterimakasih kepada Program Penelitian Ungulan Perguruan Tinggi (PUPT) Kemenristekdikti 2017 atas dukungan dana dalam penelitian ini.

\section{DAFTAR PUSTAKA}

E. Mediastika, Material Akustik Pengendali Kualitas Bunyi pada
Bangunan. Yogyakarta, 2009.

[2] A. Wirajaya, "Karakteristik Komposit Sandwich Serat Alami Sebagai Absorber Suara," Bandung, 2007.

[3] Kalita, Ujjal, A. Pratap, and S. Kumar., "Absorption Materials Used In Muffler A Review," Int. J. Mech. Ind. Technol., vol. 2, no. 2, pp. 31-37, 2015

[4] Shinoj, "Oil palm fiber (OPF) and its composites," Ind. Crops Prod., vol. 33, pp. 7-22, 2011.

[5] O. . Hee, "Sound Absorption Performance Of Oil Palm Empty Fruit Bunch Fibers," 2016.

[6] M. Farid, H. Ardhyananta, V. M. Pratiwi, and S. P. Wulandari, "Correlation between Frequency and Sound Absorption Coeffiecient of Polymer Reinforced Natural Fibre," Adv. Mater. Res., vol. 1112, pp. 329-332, 2015.

[7] M. Farid and T. Heryanto, "Correlation of Normal Incidence Sound Absorption Coefficient (NAC) and Random incidence Sound Absorption Coeffiecient (RAC) of Polyester/Ramie Fibre Composite Materials," Adv. Mater. Res., vol. 789, pp. 269-273, 2013.

[8] X. M. Dong, J. V. Revol, and D. G. Gray, "Effect of Microcrystallite Preparation Conditions on the Formation of Colloid Crystals of Cellulose," Cellulose, vol. 5, pp. 19-32, 1998.

[9] M. Pääkkö and et al, "Enzymatic Hydrolysis Combined with Mechanical Shearing and High-Pressure Homogenization for Nanoscale Cellulose Fibrils and Strong Gels," Biomacromolecules, vol. 8, pp. 1934-1941, 2007.

[10] Avba, "JEM 1400 Plus Electron Microscope," 2014. [Online]. Available:

http://www.avba.co.il/image/users/390742/ftp/my_files/JEOLJEM-1400Plus - Brochure.pdf?id=28918316.

[11] ASTM Standard E986, "Scanning Electron Microscpe Beam Size Characterization," 2004.

[12] Anonymous, "Inspect S50 Easy to use mainstream SEM enabling quick, accurate answers," 2014. [Online]. Available: http://www.fei.co.jp/_documents/DS0018-05-2014_Inspect_S50WEB.pdf.

[13] G. Mondragon, "A common strategy to extracting cellulose nanoentitiesfrom different plants," Ind. Crops Prod., vol. 55, pp. 140-148, 2014.

[14] A. Johari, Isolation, Characterization, and Application of Nanocellulose from Oil Palm Empty Fruit Bunch Fiber as Nanocomposite. Hindawi Publishing Corporation, 2014. 